The head of the cosmonaut training programme, Lieutenant General Vladimir Shatalov, has spoken in terms of a three-man crew, consisting of a Soviet commander and a flight engineer and research engineer from other Comecon countries. This suggests either a return to re-entry in shirtsleeves or else the use of a larger spacecraft, and Shatalov has indicated that "in time" larger orbiting stations will be used, making it possible for the crews to include specialists from different fields. But he did not make it clear whether such stations would be in use by 1983, and present plans for Comecon participation go no furthèr than this date.

It remains to be seen whether such joint missions form an integral feature of long term Soviet space planning, or whether, as in the case of the flight of the first (and only) woman cosmonaut Valentina Tereshkova, a policy hailed as a triumph of socialism may later be quietly phased out. The manned programme, however, is by no means the only new development of Interkosmos, nor in the long term is it the most significant.

Petrov and Gröte speak rather vaguely of Comecon participation in "still more complex and interesting experiments". This may mean no more than the provision of equipment for Soviet spacecraft, a development that is virtually implicit in the "integration" policy which aims at increasing specialisation of the member countries. But Comecon is also to provide some of the ground facilities. Already the Comecon countries track the Soviet spacecraft. The accession of Cuba to Comecon provided an important new link in the network; new plans include the provision of various research facilities. A new astronomical observatory was recently opened in Prague as part of the Interkosmos programme.

Poland's contribution will be considerable - a Space Studies Centre within the Polish Academy of Sciences to include institutes of space physics and geodesy, earth and environmental resources, the application of space technologies, materials testing, and also a computer centre. According to Professor Stefan Piotrowski, a member of the Polish Academy of Sciences and also of the Interkosmos Council, the centre will work on methods of research into the effect of solar activity on the ionosphere and atmosphere which, he says, will benefit communications, meteorology, agriculture and possibly medicine. The council will also draw up a programme of experiments to be carried out by manned spacecraft and satellites.

Although such facilities are designated part of the Interkosmos programme, it seems inevitable that the Soviet Union's own national space programme will also benefit from access to them; indeed, this would provide a further opportunity for "fraternal cooperation". However, certain joint Comecon projects have already evoked the criticism that the Soviet Union has made little contribution other than a site or the expertise, while the financial burden has fallen on her partners. However great the official acclaim of such cooperation, the possibility remains that those scientists already disenchanted with Comecon countries may view the new developments in the space programme not so much as a triumph for fraternal integration as a way for the Soviet Union to get routine research and development done at someone else's expense.

\title{
NETHERLANDS
}

\section{An unfavourable climate}

Casper Schuuring reports on recent developments in science policy in Holland

THE Dutch Government is going to spend 2,560 million guilders (about £640 million) for research in 1977. Universities will use less than half (1,130 million), after a budget this year of 2,300 million. Industry plans to have 2,810 million guilders available next year for research and development after 2,510 million this year; at the end of last year industry had expected to spend 2,190 million in 1976, indicating that the climate for investment in research is not as favourable as it seemed. Some 390 guilders will be spent on research and development per head of the population.

These figures are part of the new budget presented to parliament by the science policy minister, Fokele Trip. $\mathrm{He}$ says science policy cannot be seen apart from the socio-economic development of the country: out of science policy a contribution should come to the selective growth of the economy which the government has outlined in the government memorandum on industrial policy issued earlier this year. Environmental factors, town and country plan- ning and a policy to avoid the wasteful use of energy and resources all form part of that selective growth policy.

On the energy front 60 million guilders will be available for research as the specially formed fund for the sodium-cooled fast breeder reactor in Kalkar will be abolished. This will be used mainly for programmes other than in the nuclear field. It is surprising, however, that in the plans for research up to 1981 which were presented along with the science budget, the nuclear energy component will increase while the total energy research and development budget will hardly be more in 1981 than in 1977. The future for alternative energy sources is therefore looking very bright at the moment.

$\mathrm{Mr}$ Trip is also planning to spend more money for a popularisation of science. For five years the University of Amsterdam has organised courses for scientists to write articles for a larger audience beyond their own discipline, and it will now receive a government subsidy. Other universities are also starting such a course. At the School for Journalism a training-course for science writing will also be introduced with ministerial money, and the Royal Dutch Academy of Sciences is conducting a study on a science information unit to improve "science-

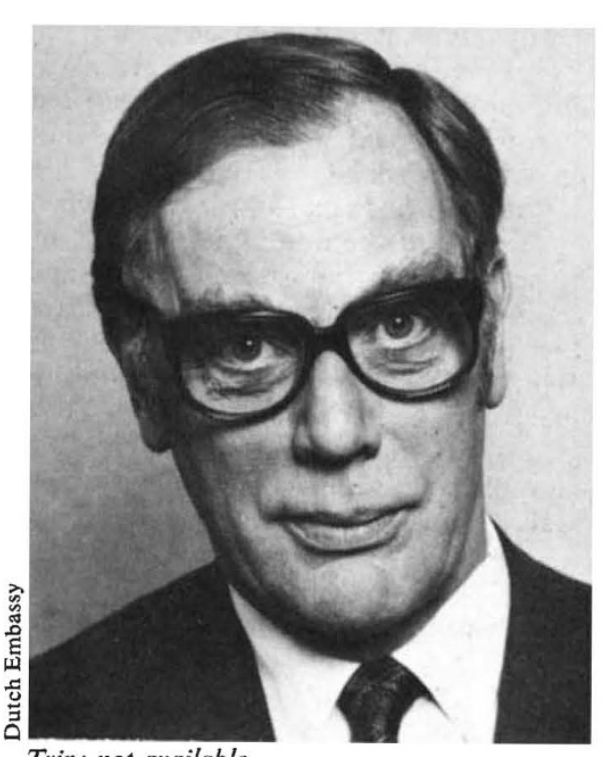

Trip: not available

society" communications; Dutch universities and some research institutes are, however, already more or less active in this respect.

The science budget received a favourable reception in the parliament's special commission on science policy. $\mathrm{Mr}$ Trip has said that for personal reasons he is not available for a government post after the elections in May 1977, and feels that a new minister for science policy is necessary. He says he will leave behind a sort of "last will" describing how best the position of such a minister can be used. 